\title{
Effects of ammonium on hydroxyl and lattice stability of phengite at high temperature and high pressure
}

\author{
WENDI LIU ${ }^{1 *}$, YAN YANG ${ }^{1}$, QUNKE XIA ${ }^{1}$ \\ ${ }^{1}$ Key Laboratory of Geoscience Big Data and Deep Resource \\ of Zhejiang Province, School of Earth Sciences, \\ Zhejiang University, Hangzhou, 310027, China \\ ( ${ }^{*}$ correspondence: wdliu@zju.edu.cn)
}

Phengite is an essential mineral carrying both hydrogen and nitrogen to the deep earth. Recently, we revealed the links between ammonium and dehydration in phengite, that is, ammonium can promote hydrogen diffusion in phengite ${ }^{[1]}$. Since volatiles release in subduction zones is mainly controlled by the stability of hydrous minerals, here, we carried out investigations on ammonium effects on the stability of phengite at an atomic level. Using in situ high temperature and high pressure IR and Raman spectroscopy, we characterized the behavior of hydroxyl and lattice in ammonium-bearing and ammonium-free phengites at high temperatures to $800{ }^{\circ} \mathrm{C}$ and high pressures to $20 \mathrm{GPa}$. We find that both temperature and pressure can induce $\mathrm{O}-\mathrm{H}$ band weakening and hydrogen disordering in phengite. The $\mathrm{O}-\mathrm{H}$ band shifts to lower frequencies with increasing temperature and pressure. The band width of hydroxyl increases at elevated temperatures and pressures. Moreover, the lattice modes soften upon heating whereas stiffen under compression. Most importantly, the ammonium effects on lattice stability are stronger at high temperatures than under high pressures. The temperature of ammonium-bearing phengite breakdown is lower than ammonium-free phengite. This study further highlights the role of ammonium in water release in subduction zones.

[1] Liu et al., 2019. Earth Planet. Sci. Lett. 513, 95-102. 